\title{
THE NATURE OF THE HUMAN FACTOR IN INFANTILE PARALYSIS. II. RELATION OF AGE TO MATURING ACHIEVEMENT AND THE DISEASE PICTURE ${ }^{1}$
}

\author{
BY GEORGE DRAPER AND C. WESLEY DUPERTUIS \\ (From the Department of Medicine, College of Physicians and Surgeons, Columbia University \\ and the Presbyterian Hospital, New York City)
}

(Received for publication October 7, 1938)

In the first paper of this series the susceptible human organism's state of growth and development was under discussion, and the retarded or incomplete phenotype which seemed to correlate highly with susceptibility was compared with well children (1).

The present paper attempts to explore the genetic and constitutional basis of the difference between sick and well, the relation of various age levels to susceptibility, and to the location of paralysis.

It would seem that the ages of 6 to 7 (second dendition) and that of 11 to 15 (puberty) are more or less critical ones in the organism's march to completeness. The controls pass through these time points without much change in their growth rates. The poliomyelitics, on the other hand, seem to be in some way stimulated to a sudden size increase following the achievement of each of these two age levels. But this stimulus does not serve to advance their already retarded development (see (1), p. 13). The controls apparently either receive no such stimulus or do not react to it. Their growth and development processes move on in parallel, undisturbed, and as a more average continuum.

Age of onset. We are ever impressed by the relationship between growth, development, age, and the moment of disease onset. There is here, however, a danger of possible confusion in the fields of cause and effect. It might be said for example that the disease itself provokes some change in the growth and maturing processes which result in the organism's failure to achieve completeness. In upholding our belief, however, that these 4 phenomena just mentioned are genetic, truly constitutional ones, and not conditioned by the disease, we can refer first to the fact that "style" of organ development is definitely

1 The work reported in this communication was carried out under a grant by the Rockefeller Foundation. hereditary. Thus the form and position of teeth are due to that same cause whether spaced or close-set. Moreover, there is a fairly high percentage ( 42.67 per cent) of close-set teeth among those children who became ill before the eruption of the second dentition. Tables I and II form the basis for these views.

These tables indicate that there are no significant differences in frequency of black spots, large central incisors, long curved eyelashes or internal eyefolds between those children who became paralyzed before 7 years of age and those who were afflicted at a later age. On the other hand there are significant differences between the two age groups in only two of the six characters, namely, central incisor spacing and pronounced hyperextensibility of the joints. The higher percentages for these two traits are found among those children who became ill during the first 6 years of life. But it was pointed out in the first paper that these characters tend to disappear with increasing years in both sick and well; the former more slowly and often less completely than the latter. As a result of these observations, it would seem that the specific characters just discussed are marks of an inherited special constitutional type and not products of the disease. Furthermore, a fair percentage of all the characters are found also among the control group. We conclude from the above that paralyzed children, no matter at what age they were measured and observed, have possessed those characters from birth.

In our discussion of the six characters which were found with much greater frequency in the sick group, we took into consideration only the percentage distribution of these characters as compared to the control series. It may well be of equal importance to examine the quantitative distribution of these characters among the sick and the well. In Table III and the subsequent tables the Roman numerals refer to the number of the 
TABLE I

Percentage distribution of characters according to age at onset of disease. Paralyzed boys. Age 7 and over (when measured)

\begin{tabular}{|c|c|c|c|c|c|c|}
\hline Age of onset & \multicolumn{3}{|c|}{ Number } & \multicolumn{3}{|c|}{ Per cent } \\
\hline $\begin{array}{l}\text { Before } 7 \text { years.... } \\
7 \text { years and above. }\end{array}$ & \multicolumn{3}{|c|}{$\begin{array}{l}75 \\
50\end{array}$} & \multicolumn{3}{|c|}{$\begin{array}{l}60.00 \\
40.00\end{array}$} \\
\hline \multicolumn{7}{|c|}{ Black spots } \\
\hline \multirow{2}{*}{ Age at onset } & \multicolumn{2}{|c|}{ Absent } & \multicolumn{2}{|c|}{ Present } & \multicolumn{2}{|c|}{ Total } \\
\hline & Num- & $\begin{array}{c}\text { Per } \\
\text { cent }\end{array}$ & $\underset{\text { ber }}{\text { Num- }}$ & $\begin{array}{l}\text { Per } \\
\text { cent }\end{array}$ & Num- & $\begin{array}{l}\text { Per } \\
\text { cent }\end{array}$ \\
\hline $\begin{array}{l}\text { Before } 7 \text { years. ... } \\
7 \text { years and above. }\end{array}$ & $\begin{array}{l}5 \\
1\end{array}$ & $\begin{array}{l}6.67 \\
2.00\end{array}$ & $\begin{array}{l}70 \\
49\end{array}$ & $\begin{array}{l}93.33 \\
98.00\end{array}$ & $\begin{array}{l}75 \\
50\end{array}$ & $\begin{array}{l}100.00 \\
100.00\end{array}$ \\
\hline \multicolumn{7}{|c|}{ Eyelashes } \\
\hline \multirow{2}{*}{ Age at onset } & \multicolumn{2}{|c|}{$\begin{array}{c}\text { Short and } \\
\text { medium }\end{array}$} & \multicolumn{2}{|c|}{ Long curved } & \multicolumn{2}{|c|}{ Total } \\
\hline & Num- & $\begin{array}{l}\text { Per } \\
\text { cent }\end{array}$ & Num- & $\begin{array}{c}\text { Per } \\
\text { cent }\end{array}$ & Num- & $\begin{array}{c}\text { Per } \\
\text { cent }\end{array}$ \\
\hline $\begin{array}{l}\text { Before } 7 \text { years.... } \\
7 \text { years and above. }\end{array}$ & $\begin{array}{l}10 \\
14\end{array}$ & $\begin{array}{l}13.33 \\
28.00\end{array}$ & $\begin{array}{l}65 \\
36\end{array}$ & $\begin{array}{l}86.67 \\
72.00\end{array}$ & $\begin{array}{l}75 \\
50\end{array}$ & $\begin{array}{l}100.00 \\
100.00\end{array}$ \\
\hline
\end{tabular}

Hyperextensibility of joints

\begin{tabular}{c|c|c|c|c|c|c}
\hline \multirow{2}{*}{ Age at onset } & \multicolumn{2}{|c|}{$\begin{array}{c}\text { Absent to } \\
\text { medium }\end{array}$} & \multicolumn{2}{|c|}{ Pronounced } & \multicolumn{2}{|c}{ Total } \\
\cline { 2 - 6 } & $\begin{array}{c}\text { Num- } \\
\text { ber }\end{array}$ & $\begin{array}{c}\text { Per } \\
\text { cent }\end{array}$ & $\begin{array}{c}\text { Num- } \\
\text { ber }\end{array}$ & $\begin{array}{c}\text { Per } \\
\text { cent }\end{array}$ & $\begin{array}{c}\text { Num- } \\
\text { ber }\end{array}$ & $\begin{array}{c}\text { Per } \\
\text { cent }\end{array}$ \\
\hline $\begin{array}{c}\text { Before 7 years.... } \\
\text { 7 years and above. }\end{array}$ & 24 & 32.00 & 51 & 68.00 & 75 & 100.00 \\
& 27 & 54.00 & 23 & 46.00 & 50 & 100.00 \\
\hline
\end{tabular}

Central incisor spacing

\begin{tabular}{c|c|c|c|c|c|c}
\hline \multirow{2}{*}{ Age at onset } & \multicolumn{2}{|c|}{ Absent } & \multicolumn{2}{c|}{ Present } & \multicolumn{2}{c}{ Total } \\
\cline { 2 - 7 } & $\begin{array}{c}\text { Num- } \\
\text { ber }\end{array}$ & $\begin{array}{c}\text { Per } \\
\text { cent }\end{array}$ & $\begin{array}{c}\text { Num- } \\
\text { ber }\end{array}$ & $\begin{array}{c}\text { Per } \\
\text { cent }\end{array}$ & $\begin{array}{c}\text { Num- } \\
\text { ber }\end{array}$ & $\begin{array}{c}\text { Per } \\
\text { cent }\end{array}$ \\
\hline Before 7 years.... & 32 & 42.67 & 43 & 57.33 & 75 & 100.00 \\
7 years and above. & 35 & 70.00 & 15 & 30.00 & 50 & 100.00 \\
\hline
\end{tabular}

Internal eyefolds

\begin{tabular}{c|c|c|c|c|c|c}
\hline \multirow{2}{*}{ Age at onset } & \multicolumn{2}{|c|}{ Absent } & \multicolumn{2}{c|}{ Present } & \multicolumn{2}{c}{ Total } \\
\cline { 2 - 7 } & \begin{tabular}{c|c|c|c} 
Num- \\
ber
\end{tabular} & $\begin{array}{c}\text { Per } \\
\text { cent }\end{array}$ & $\begin{array}{c}\text { Num- } \\
\text { ber }\end{array}$ & $\begin{array}{c}\text { Per } \\
\text { cent }\end{array}$ & $\begin{array}{c}\text { Num- } \\
\text { ber }\end{array}$ & $\begin{array}{c}\text { Per } \\
\text { cent }\end{array}$ \\
\hline Before 7 years.... & 41 & 55.41 & 33 & 44.59 & 74 & 100.00 \\
7 years and above. & 29 & 58.00 & 21 & 42.00 & 50 & 100.00 \\
\hline
\end{tabular}

Large central incisors

\begin{tabular}{c|c|c|c|c|c|c}
\hline \multirow{2}{*}{ Age at onset } & \multicolumn{2}{|c|}{ Absent } & \multicolumn{2}{c|}{ Present } & \multicolumn{2}{c}{ Total } \\
\cline { 2 - 7 } & $\begin{array}{c}\text { Num- } \\
\text { ber }\end{array}$ & $\begin{array}{c}\text { Per } \\
\text { cent }\end{array}$ & $\begin{array}{c}\text { Num- } \\
\text { ber }\end{array}$ & $\begin{array}{c}\text { Per } \\
\text { cent }\end{array}$ & $\begin{array}{c}\text { Num- } \\
\text { ber }\end{array}$ & $\begin{array}{c}\text { Per } \\
\text { cent }\end{array}$ \\
\hline Before 7 years.... & 12 & 16.00 & 63 & 84.00 & 75 & 100.00 \\
7 years and above. & 12 & 24.00 & 38 & 76.00 & 50 & 100.00 \\
\hline
\end{tabular}

TABLE II

Differences of percentages of observations on paralyzed boys who became sick before 7 years of age and those who became afflicted at 7 years or after with value in terms of probable error.

Age of onset before 7 years/Age of onset 7 years or above

\begin{tabular}{|c|c|}
\hline Difference & xpe \\
\hline $\begin{array}{l}\text { 1. Black spots-Present . . . . } \ldots \ldots \ldots \ldots-4.67 \\
\text { 2. Eyelashes-Long, curved } \ldots \ldots \ldots \ldots+14.67 \\
\text { 3. Hyperextensibility of joints- }\end{array}$ & $\begin{array}{r}-1.98 \\
+2.92\end{array}$ \\
\hline $\begin{array}{l}\text { Pronounced................. } \\
\text { 4. Central incisor spacing-Present } \ldots \ldots+27.00 \\
\text { 5. Internal eyefolds-Present ....... } \\
\text { 6. Large central incisors-Present } \ldots \ldots+8.59 \\
\text {. }\end{array}$ & $\begin{array}{l}+3.68 \\
+4.70 \\
+.42 \\
+1.61\end{array}$ \\
\hline
\end{tabular}

TABLE III

Table showing percentage distribution of six characters among sick boys and girls and control boy series

\begin{tabular}{lll}
\hline \hline Num- & $\begin{array}{c}\text { Per } \\
\text { cent }\end{array}$ \\
\hline
\end{tabular}

Paralyzed boys-Ages 7 and over

VI Six characters present............ $10 \quad 8.00$

V Five characters present. . . . . . . . . 40 40.00

IV Four characters present............... $39 \quad 31.20$

III Three characters present . . . . . . . . . $27 \quad 21.60$

II Two characters present ................ 99

I One character present............ 0

0 None present.................... 0

0

$125 \quad \overline{100.00}$

Summary

3 or more characters present . . . . . . . ...116 92.80

4 or more characters present . . . . . . . . . 89

2 or less characters present............ 997.20

Paralyzed girls-Ages 7 and over

VI Six characters present. ............ 17

V Five characters present ............... 29

IV Four characters present ............ 30

III Three characters present . . . . . . . . . 18

II Two characters present ............ 7

I One character present.............. 5

0 None present. . . . . . . . . . . . . . . . 1

$\overline{107}$

Summary

3 or more characters present . . . . . . . . 94

4 or more characters present. . . . . . . . . 76

2 or less characters present........... 13

15.89

27.10

28.04

16.82

6.54

.93

99.99

87.85

71.03

12.15

Control series, boys-Ages 7 and over

VI Six characters present ............ 3

V Five characters present................. 16

IV Four characters present .............. 32

III Three characters present . . . . . . . . . 55

II Two characters present $. . \ldots \ldots \ldots \ldots \ldots, 65$

I One character present $\ldots \ldots \ldots \ldots \ldots \ldots, 30$

0 None present . . . . . . . . . . . . . . 8

Summary

1.44

7.66

15.31

26.32

31.10

14.35

3.82

100.00

3 or more characters present . . . . . . . 106

4 or more characters present . .......... 51

2 or less characters present ...............

50.72

24.40

49.28 
six characters possessed by the members of each group. Thus, for example, the numeral VI means that all six of the chosen characters are present. On the other hand, II represents those individuals who possess only two of the six characters.

A glance at the summaries shows for example that among the sick boys, 7.20 per cent possess only two characters or less, whereas among the controls 49.28 per cent have two or less. Furthermore among the stricken, 92.8 per cent have three or more of the six characters and the well who possess three or more form but 50.72 per cent. The figures for girls parallel those of the boys very closely.

There is also a correlation between the number of characters a child shows and the age at which he is measured. That is, those individuals in the male paralyzed group, for example, who have the least number of the six characters are among the oldest. Those who have the largest number of characters tend to be the youngest. This is true also for the control group. The demonstration of this fact is represented by the coefficient of mean square contingency for age (at the time of measurement) and number of characters. The figures are 0.56 for the sick boys and 0.51 for the control group of well boys. In other words, if age and number of characters be correlated, it appears that the sick individuals average more of the six characters than the well, but their loss in relation to increasing ages follows a parallel course. If we take into account, however, the age at which these sick children became paralyzed we have a somewhat different picture. We have found, for example, that of the group of 9 sick children (Table IV) who exhibited only two of the six characters none were below 11 years of age when measured. Seven of these 9 children, however, got the disease at 7 years of age or later and only 2 before 7 years. Of the 10 boys who exhibited all six characters, 8 or 80 per cent got the disease before 7 years of age and only 2 or 20 per cent at 7 years of age or after. The figures for the girls are even more striking (Table V).

From the foregoing, then, it appears that even though there is a correlation between age (when measured) and the number of characters possessed by these paralyzed children we find also a
TABLE IV

Paralyzed boys-Ages 7 and over

\begin{tabular}{|c|c|c|c|c|}
\hline \multirow{2}{*}{$\begin{array}{l}\text { Number of } \\
\text { characters } \\
\text { possessed }\end{array}$} & \multicolumn{2}{|c|}{$\begin{array}{c}\text { Age at onset before } \\
7 \text { years }\end{array}$} & \multicolumn{2}{|c|}{$\begin{array}{l}\text { Age at onset } 7 \text { years } \\
\text { and above }\end{array}$} \\
\hline & Number & Per cent & Number & Per cent \\
\hline $\begin{array}{l}\text { II } \ldots \ldots \\
\text { III } \ldots \ldots \\
\text { IV } \ldots \ldots \\
\text { V. } \ldots \ldots \\
\text { VII } \ldots \ldots\end{array}$ & $\begin{array}{r}2 \\
12 \\
22 \\
28 \\
8\end{array}$ & $\begin{array}{l}22.22 \\
44.44 \\
56.41 \\
70.00 \\
80.00\end{array}$ & $\begin{array}{r}7 \\
15 \\
17 \\
12 \\
2\end{array}$ & $\begin{array}{l}77.78 \\
55.56 \\
43.59 \\
30.00 \\
20.00\end{array}$ \\
\hline
\end{tabular}

TABLE $v$

Paralyzed girls-Ages 7 and over

\begin{tabular}{|c|c|c|c|c|}
\hline \multirow{2}{*}{$\begin{array}{l}\text { Number of } \\
\text { characters } \\
\text { possessed }\end{array}$} & \multicolumn{2}{|c|}{$\begin{array}{c}\text { Age at onset before } \\
7 \text { years }\end{array}$} & \multicolumn{2}{|c|}{$\begin{array}{l}\text { Age at onset } 7 \text { years } \\
\text { and above }\end{array}$} \\
\hline & Number & Per cent & Number & Per cent \\
\hline $\begin{array}{l}\operatorname{I} \ldots \ldots \\
\text { II } \\
\text { III } \cdots \cdots \\
\text { IV } \ldots \cdots \\
\text { V. } \cdots \cdots \\
\text { VII } \ldots \ldots\end{array}$ & $\begin{array}{r}1 \\
2 \\
7 \\
18 \\
18 \\
11\end{array}$ & $\begin{array}{l}20.00 \\
28.57 \\
41.18 \\
60.00 \\
72.00 \\
78.43\end{array}$ & $\begin{array}{r}4 \\
5 \\
10 \\
12 \\
7 \\
3\end{array}$ & $\begin{array}{l}80.00 \\
71.43 \\
58.82 \\
40.00 \\
28.00 \\
21.43\end{array}$ \\
\hline
\end{tabular}

correlation between age of onset of the disease and the number of characters exhibited at the time of measurement. Thus, those children who possess a larger number of the six characters had a tendency to develop the disease at an early age.

At this point it might be of interest to determine which of the selected six characters appeared most frequently in the sortings on both groups of paralyzed children and the control sample of well boys. In a comprehensive ranking table we have listed the traits in order of their frequency in the sick and control groups (Table VI). For example, black spots were found in the highest percentage of the sick boys and girls irrespective of whether they possessed one or six of the six characters. Black spots take second place in the series of well boys and large central incisors the leading position.

From Table VI we see that the well boys do exhibit fairly high percentages for certain of the six selected characters. For example the highest is that of $\mathbf{5 2 . 6 3}$ per cent for large central incisor teeth. But, on the other hand, the lowest percentage for any character among the afflicted group is 47.94 per cent. When, however, one compares the occurrence of the character of internal eyefolds among sick and well, it appears 
TABLE VI

Percentage distribution of the six characters

\begin{tabular}{|c|c|c|c|c|c|c|c|c|}
\hline \multirow[t]{2}{*}{ Paralyzed boys } & \multicolumn{2}{|r|}{146} & \multicolumn{2}{|l|}{ Paralyzed girls } & 124 & \multicolumn{2}{|l|}{ Well boys } & 214 \\
\hline & $\underset{\text { ber }}{\text { Num- }}$ & $\begin{array}{c}\text { Per } \\
\text { cent }\end{array}$ & & Num- & $\begin{array}{l}\text { Per } \\
\text { cent }\end{array}$ & & $\underset{\text { ber }}{\text { Num- }}$ & $\begin{array}{c}\text { Per } \\
\text { cent }\end{array}$ \\
\hline $\begin{array}{l}\text { 1. Black spots present } \\
\text { 2. Large central incisors* } \\
\text { 3. Long eyelashes }\end{array}$ & $\begin{array}{l}137 \\
114 \\
119\end{array}$ & $\begin{array}{l}93.84 \\
91.20 \\
81.51\end{array}$ & $\begin{array}{l}\text { 1. Black spots present } \\
\text { 2. Large central incisorst } \\
\text { 3. Hyperextensibility of }\end{array}$ & $\begin{array}{r}114 \\
89 \\
94\end{array}$ & $\begin{array}{l}91.94 \\
83.18 \\
75.81\end{array}$ & $\begin{array}{l}\text { 1. Large central incisors } \\
\text { 2. Black spots present } \\
\text { 3. Long eyelashes }\end{array}$ & $\begin{array}{r}110 \\
101 \\
95\end{array}$ & $\begin{array}{l}52.63 \\
47.20 \\
44.39\end{array}$ \\
\hline $\begin{array}{l}\text { 4. Hyperextensibility of } \\
\text { joints pronounced }\end{array}$ & 94 & 64.38 & 4. Long eyelashes & 89 & 71.77 & $\begin{array}{l}\text { 4. Hyperextensibility of } \\
\text { joints pronounced }\end{array}$ & 81 & 37.85 \\
\hline $\begin{array}{l}\text { 5. Central incisor spacing } \\
\text { 6. Internal eyefolds }\end{array}$ & $\begin{array}{l}78 \\
70\end{array}$ & $\begin{array}{l}53.42 \\
47.94\end{array}$ & $\begin{array}{l}\text { 5. Internal eyefolds } \\
\text { 6. Central incisor spacing }\end{array}$ & $\begin{array}{l}69 \\
68\end{array}$ & $\begin{array}{l}55.64 \\
54.84\end{array}$ & $\begin{array}{l}\text { 5. Central incisor spacing } \\
\text { 6. Internal eyefolds }\end{array}$ & $\begin{array}{l}78 \\
51\end{array}$ & $\begin{array}{l}36.45 \\
23.83\end{array}$ \\
\hline
\end{tabular}

* Based on 125 cases of age 7 years and above.

† Based on 107 cases of age 7 years and above.

$\ddagger$ Based on 209 cases of age 7 years and above.

that 47.94 per cent of the former possess it, and only 23.83 per cent of the latter.

A good deal of speculation has been spent over the factors which determine the distribution of the paralyses in any given case. There has never seemed to be any rhyme or reason for the irregular and varying involvement of an arm here, a leg there, a diaphragm, or glottis. Our investigation of this point shows first that lower extremity paralysis outnumbers by a great margin any other group of muscles. This is old knowledge. Statistical analysis of paralysis location in relation to age at the time of attack, however, shows that $\mathbf{5 7 . 7 5}$ per cent of those children who were stricken during the first 7 years of life were paralyzed only in the lower extremities. Only 14.08 per cent of this age epoch were extensively paralyzed in trunk and limbs (general). The boys of the age epoch 7 and over, on the other hand, had a different record. In their case only 24.49 per cent suffered lower extremity paralysis whereas 32.65 per cent had general involvement. These differences are statistically significant. The relation of number of characters and age-paralysis distribution is not absolute. In the children stricken under 7 years of age there is a tendency for the possessors of five and six characters to be paralyzed in the lower extremities with much greater frequency than in other parts of the body. On the other hand, those individuals maimed after 7 years of age and who possess fewer of the six characters display a greater trend toward upper extremity and more general involvement.
The greater frequency of lower extremity paralysis has always been an unexplained and challenging phenomenon of poliomyelitis. Our figures seem to show that children afflicted at a very early age are more apt to develop lower extremity paralysis than those afflicted at an older age. If one were to theorize upon the significance of this observation, one is led to consider the fundamental biology of extremity development in quadrupeds generally. It is well known that in such forms, including man, the anterior limb buds appear first and for 2 years at least, following their appearance, take the lead in size and coordination of movements. Presumably the cervical enlargement of the cord parallels this growth. We do not know, however, what the relationship is during growth and development between maturing achievement and local tissue resistance to the virus attack upon the anterior horn cells. Variations in general immunity in relation to age are well known however.

The data seem to show two things. The first is that individuals possessing 5 or 6 of the specific criteria tend on the one hand to have contracted the disease at an early age. Secondly, their paralyses involve the extremities, especially the lower. On the other hand, the children who develop their disease between 7 years and puberty more often appear to possess relatively few of the six characters. Furthermore, the paralysis of this age span is much more apt to involve arms and trunk relatively more often than is the case in the younger group. Cases which arise be- 
tween puberty and full adulthood tend not only to a similar generalization of paralysis but also to increased severity of the clinical course. Thus, for example, among the 23 boys who were 15 years or over when measured in 1938, 10 did did not contract the disease until the 1935 epidemic at which time they were 13 or older; and at the time of the large 1931 epidemic were 9 or older. Of these, 70 per cent developed widespread paralyses of the trunk and extremities. The majority of the members of this group did not have more than three of the selected characters. Why these boys who possessed criteria of susceptibility resisted the virus in the very active 1931 epidemic and succumbed with severe attacks in 1935 is at present unanswerable. But in view of the principle of total organismal growth and development, it may be significant.

The purpose of the foregoing study has been to show that from the morphological standpoint alone children who develop infantile paralysis are definitely different from those who resist the virus. From our point of view, human morphology is significant only insofar as it correlates with other characters of the total personality. As yet we have made no studies of other panels of the total personality of infantile paralysis patients.

The preceding paper (1) and the present one have reported a fairly large group of sick and an even larger control group of well children studied by morphological and statistical methods. As far as appears, the original observations from this clinic on morphology of infantile paralysis subjects have been largely substantiated by the analysis, and through this medium possibly some new thoughts about the nature of the disease have emerged.

In addition to the well known fact that young children are most frequently attacked, there seem to be certain peculiarities about the disease which show that the time or age factor is related to susceptibility throughout the course of growth and development. Thus, for example, the differences in growth rhythm between the sick and control series is one instance of this force (1). Variations in teeth size and placement, fat contours and genital irregularities, and retardations provide other examples; while still others are found in the bony arrangements of eye zone, eye form and folds. Finally, the retention by the susceptible group of many development criteria common to the fetus and infant such as wide inter-inner canthus space, internal eyefolds, separated incisors, and hyperextensibility of finger joints, still further emphasize the point in the field of development. The importance of pigment irregularities, especially in the form of small black spots, is definitely the most outstanding and obscure feature. In addition to the points summarized from the first paper, the present study deals with the level of maturing achievement (age, biological time?) at the moment of disease onset, the number of the six characters present, and the location of the paralyses.

\section{CONCLUSIONS}

1. The special constitutional qualities of persons susceptible to infantile paralysis are the result of genetic or adverse intrauterine influences and not the product of the disease.

2. Paralyzed individuals show a higher percentage of a greater number of the six characters than do the well.

3. There is a correlation between the number of characters a child shows and the age at which he was measured. This is true for both paralyzed and well children although the former show a larger percentage of these characters at every age level.

4. There is also a correlation between the age of onset of the disease and the number of characters exhibited at the time of measurement.

5. Both paralyzed and control groups possess one or all six characters. But in every character the stricken persons possess them in higher percentage. Furthermore, the highest percentage in any one character of the well group (52.63 per cent) is only 5.7 per cent higher than the lowest of the sick (47.94 per cent). In every case the percentage difference for a given character is significantly higher for the paralyzed group.

6. Individuals stricken before 7 years of age have the highest percentage of lower extremity paralysis and the least upper extremity and general involvement. Those who develop the disease after the seventh year show a high percentage of upper extremity and general paralysis. 
7. Children stricken under seven years of age show (1) higher percentage of lower extremity paralysis and (2) possess a greater number of the six characters.

Thanks are due to the New York State Reconstruction Hospital at Haverstraw, N. Y.; New York Hospital for Ruptured and Crippled, Hospital for Joint Diseases, New York Orthopedic Hospital, New York City; Kings County Hospital and St. Gile's Hospital, Brooklyn. We are further greatly indebted to Mr. Albert B. Hines, Director of the Madison Square Boys' Club, for his courtesy and cooperation in providing the control material.

\section{BIBLIOGRAPHY}

1. Draper, G., and Dupertuis, C. Wesley, The nature of the human factor in infantile paralysis. I. Peculiarities of growth and development. J. Clin. Invest., 1939, 18, 87. 